\title{
Pengaruh Problem-Based Learning Menggunakan Praktikum Alat Sederhana Terhadap Keterampilan Berpikir Kreatif Siswa SMA Negeri 7 Palu
}

\author{
Oka Saputra, Nurjannah dan Jusman Mansyur \\ email: oucckha@gmail.com \\ Program Studi Pendidikan Fisika FKIP Universitas Tadulako \\ Jl. Soekarno Hatta Km. 9 Kampus Bumi Tadulako Tondo Palu - Sulawesi Tengah
}

\begin{abstract}
Abstrak - Tujuan penelitian yaitu untuk mengetahui peningkatan kemampuan berpikir kreatif siswa SMA Negeri 7 Palu setelah diterapkan model problem-based learning menggunakan praktikum alat sederhana. Sampel penelitian adalah siswa kelas $X_{B}$ SMA Negeri 7 Palu. Dimana sampel penelitian terdiri dari 20 orang siswa kelas $X_{B}$. Hasil analisis data menunjukkan bahwa skor rata-rata tes awal sebesar 7,8 dan skor rata-rata tes akhir sebesar 13,05. Pengujian hipotesis menggunakan uji Wicolxon (satu pihak) diperoleh $W_{\text {hitung }}=0$ $\mathrm{W}_{\text {tabel }}=60$ pada $\mathrm{a}=0,05$. Berdasarkan hasil yang diperoleh, disimpulkan bahwa terdapat peningkatan yang signifikan terhadap keterampilan berpikir kreatif siswa setelah diterapkan model Problem Based Learning menggunakan praktikum alat sederhana. Hal ini disebabkan oleh model Problem Based Learning menggunakan praktikum alat sederhana mengharuskan siswa aktif dan membiasakan untuk berpikir kreatif, hal tersebut menyebabkan siswa menyelesaikan masalah dengan cara yang fleksibel dan mempunyai alasan mengapa memilih cara tersebut (elaborasi).
\end{abstract}

Kata kunci: Model Problem Based Learning, Alat Sederhana, Praktikum dan Berpikir Kreatif

\section{PENDAHULUAN}

Melakukan praktikum adalah salah satu cara untuk mengasah kemampuan berpikir siswa dalam belajar fisika. Siswa dapat memecahkan masalah sains dengan cara menghubungkan hasil observasi dalam praktikum dengan konstruksi teoritis yang telah dimiliki sehingga dapat membangun struktur konsep dengan baik.

Mustafit [1] dalam hasil penelitiannya mengatakan bahwa kegiatan laboratorium atau yang sering dikenal dengan istilah praktikum yang selama ini dilaksanakan masih tergolong laboratorium verifikasi. Kegiatan laboratorium verifikasi merupakan kegiatan laboratorium dimana praktikan hanya melakukan kegiatannya berdasarkan petunjuk atau cara kerja yang ada pada buku petunjuk praktikum. Pengertian verifikasi laboratorium menurut peneliti merupakan kegiatan praktikum yang prosedur kerjanya telah dituliskan secara jelas didalam modul secara rinci. Petunjuk praktikum yang terlalu rinci mengakibatkan kurang mendorong siswa untuk berkreasi mengorganisir kemampuannya untuk merencanakan dan menyelesaikan persoalan yang dihadapinya. Kegiatan tersebut dapat menyebabkan siswa tidak menjadi aktif dan menjadikan kemampuan untuk berpikir kreatif siswa tidak terasah dengan baik.

Awang [2] menyimpulkan bahwa model pembelajaran Problem-Based Learning dapat meningkatkan keterampilan berpikir kreatif siswa, penelitian yang dilakukan oleh Awang memiliki kendala dimana siswa harus dibiasakan berpikir bukan untuk menghafal seperti model pembelajaran konvensional sehingga membuat siswa jenuh karena harus dihadapkan dengan permasalahan secara langsung.

Dari uraian di atas, diketahui bahwa PBL melalui metode praktikum dapat dikatakan mampu meningkatkan keterampilan berpikir kreatif siswa tetapi permasalahannya tidak 
semua sekolah memiliki alat-alat praktikum yang memadai dalam menunjang proses belajar-mengajar sehingga diperlukan alat peraga yang terdapat dalam kehidupan seharihari untuk menggantikan alat-alat praktikum yang tidak lengkap didalam suatu sekolah.

\section{METODE PENELITIAN}

Jenis penelitian ini merupakan penelitian kuantitatif yang bersifat eksperimen lemah. Sampel dalam penelitian adalah 20 siswa kelas XB SMA Negeri 7 Palu.

Desain yang digunakan dalam penelitian ini adalah "one group pretest-posttest design" yaitu penelitian yang dilaksanakan dengan hanya menggunakan satu kelas saja yang dijadikan sebagai kelas eksperimen. Desain penelitian ini dapat dilihat pada Tabel 1 berikut:

Tabel 1 Desain Satu Kelompok PretestPosttest (one group pretest-posttest design)

\begin{tabular}{|c|c|c|c|}
\hline Kelompok & Tes Awal & Perlakuan & Tes Akhir \\
\hline $\mathrm{E}$ & $\mathrm{O}_{1}$ & $\mathrm{X}$ & $\mathrm{O}_{2}$ \\
\hline
\end{tabular}

Keterangan:

$$
\begin{aligned}
\mathrm{E}: & \text { Kelas eksperimen } \\
\mathrm{X}: \text { Perlakuan dengan problem-based } & \text { learning menggunakan praktikum } \\
& \text { alat sederhana. } \\
\mathrm{O}_{1}: & \text { Tes Awal } \\
\mathrm{O}_{2}: & \text { Tes Akhir }
\end{aligned}
$$

Sebanyak 4 butir tes keterampilan berpikir kreatif diberikan kepada 20 siswa.

Berdasarkan data dari tes keterampilan berpikir kreatif, dihitung dengan menggunakan uji $\mathrm{N}$-gain dan statistik non parametrik uji wilcoxon satu pihak.

\section{HASIL PENELITIAN DAN PEMBAHASAN}

Dalam penelitian ini, instrumen yang digunakan berupa tes keterampilan berpikir kreatif yang terdiri dari 4 soal dalam bentuk uraian. Setiap item soal tes telah divalidasi oleh validator ahli.

Setelah dilakukan perhitungan tes keterampilan berpikir kreatif diperoleh data hasil penelitian seperti pada Tabel 2 .

Tabel 2 Skor Tes keterampilan berpikir kreatif

\begin{tabular}{|l|c|c|}
\hline \multicolumn{1}{|c|}{ Uraian } & $\begin{array}{c}\text { Tes } \\
\text { Awal }\end{array}$ & $\begin{array}{c}\text { Tes } \\
\text { Akhir }\end{array}$ \\
\hline Sampel & 20 & 20 \\
Skor Terendah & 5 & 8 \\
Skor Tertinggi & 11 & 16 \\
Skor Rata-rata & 7,8 & 13,05 \\
Skor Ideal & 16 & 16 \\
\hline
\end{tabular}

Berdasarkan tabel 2, dapat dilihat bahwa secara kuantitas terdapat perbedaan keterampilan berpikir kreatif siswa sebelum dan sesudah diterapkannya problem-based learning menggunakan praktikum alat sederhana.

Hasil perhitungan skor $\mathrm{N}$-gain rerata siswa dapat dilihat pada tabel 3.

Tabel $3 \mathrm{~N}$-gain

\begin{tabular}{|c|c|c|c|c|c|}
\hline No & Nama & $\begin{array}{c}\text { Skor } \\
\text { Pre } \\
\text { Test }\end{array}$ & $\begin{array}{c}\text { Skor } \\
\text { Post } \\
\text { Test }\end{array}$ & $\begin{array}{c}\text { G } \\
(\%)\end{array}$ & Kriteria \\
\hline 1 & Aldi & 9 & 12 & 42,9 & Sedang \\
\hline 2 & Balgis & 7 & 16 & 100 & Tinggi \\
\hline 3 & Desi & 7 & 16 & 100 & Tinggi \\
\hline 4 & Eva & 7 & 11 & 44,4 & Sedang \\
\hline 5 & Faega & 10 & 16 & 100 & Tinggi \\
\hline 6 & Giyan & 7 & 16 & 100 & Tinggi \\
\hline 7 & Josua & 5 & 12 & 63,6 & Sedang \\
\hline 8 & Kharis & 11 & 15 & 80 & Tinggi \\
& ma & & & & \\
\hline
\end{tabular}




\begin{tabular}{|c|c|c|c|c|c|}
\hline 9 & $\begin{array}{c}\text { Miftah } \\
\text { ul }\end{array}$ & 11 & 12 & 20 & Rendah \\
\hline 10 & $\begin{array}{c}\text { Abdha } \\
\text { ni }\end{array}$ & 7 & 11 & 44,4 & Sedang \\
\hline 11 & Rifaldi & 7 & 9 & 22,2 & Rendah \\
\hline 12 & Veyzar & 7 & 14 & 77,8 & Tinggi \\
\hline 13 & Ishak & 7 & 15 & 88,9 & Tinggi \\
\hline 14 & Nila & 6 & 16 & 100 & Tinggi \\
\hline 15 & Novita & 8 & 10 & 25 & Rendah \\
\hline 16 & Rahma & 7 & 8 & 11,1 & Rendah \\
\hline 17 & Salmi & 7 & 14 & 77,8 & Tinggi \\
\hline 18 & Shela & 11 & 15 & 80 & Tinggi \\
\hline 19 & Tri & 7 & 8 & 11,1 & Rendah \\
\hline $\begin{array}{c}20 \\
\text { Vevaln }\end{array}$ & 8 & 15 & 87,5 & Tinggi \\
\hline $\begin{array}{c}\text { Ju } \\
\text { mla } \\
\text { h }\end{array}$ & & 156 & 261 & 1277 & Sedang \\
\hline $\begin{array}{c}\text { rer } \\
\text { ata }\end{array}$ & & 7,8 & 13,0 & 63,8 & \\
\hline
\end{tabular}

Melihat harga rerata $\mathrm{N}$-gain pada tabel tersebut dapat dilihat bahwa $\mathrm{N}$-gain yang diperoleh dalam katagori sedang, hal tersebut dapat diketahui dari hasil perhitungan nilai $\mathrm{N}$ gain yang diperoleh sebesar $63 \%$.

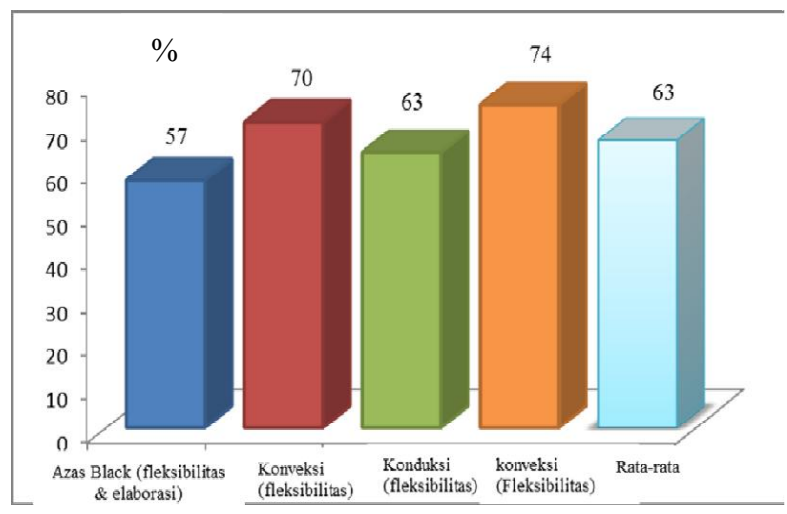

Gambar 1 Perbandingan N-gain rata-rata tiap indikator dan $\mathrm{N}$-gain rata-rata Kelas

Soal Nomor 1 memiliki peningkatan skor terendah hal tersebut disebabkan soal Nomor 1 memberikan kisi-kisi dalam memecahkan masalah sehingga peningkatan skor soal
Nomor 1 paling rendah dibanding skor nomor soal yang lain. Untuk lebih jelasnya bisa diperhatikan di Gambar 1. Terlihat jelas peningkatan keterampilan berpikir kreatif siswa kelas $X_{B}$ antara skor rata-rata tes awal dan skor rata-rata tes akhir. Skor maksimal tiap butir soal adalah 4. Tiap skor memiliki kriteria tertentu sehingga memudahkan peneliti dalam memeriksa jawaban tes berpikir kreatif siswa. Baik soal dan rubrik jawaban tes keterampilan berpikir kreatif siswa telah divalidasi oleh validator yang kompeten dibidangnya.

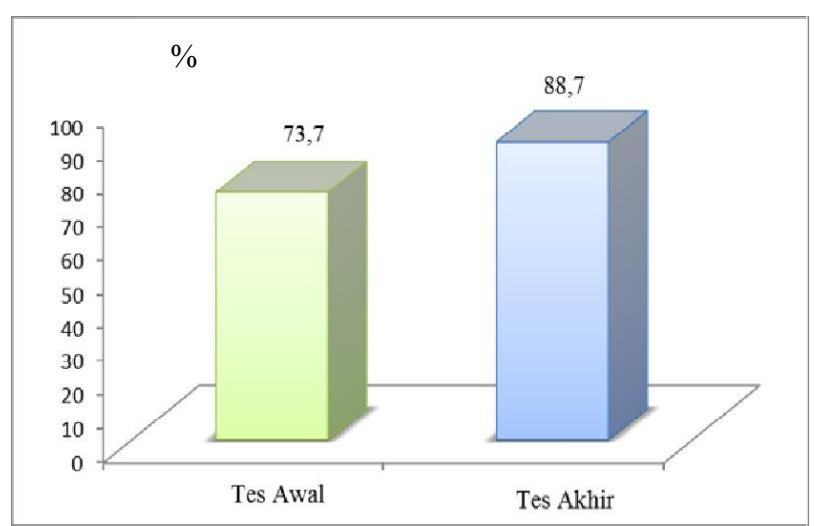

Gambar 2 Perbandingan skor rata-rata tes awal dan tes akhir soal Nomor 1

Materi soal Nomor 1 berkaitan dengan Azas Black, dapat dilihat pada Gambar 2 bahwa terjadi peningkatan antara tes awal dan tes akhir. Model pembelajaran yang dilakukan oleh peneliti membiasakan siswa dalam menyelesaikan masalah lebih dari satu cara dan acara tersebut mampu dijelaskan secara jelas oleh siswa tersebut. Buzan (2007) menyatakan bahwa kebanyakan proses belajar mengajar hanya terfokus pada otak kiri sehingga menyebabkan siswa terjebak dalam lingkungan yang tidak kreatif. Untuk membebaskan potensi kreatif perlu menumbuhkan suatu lingkungan pemikiran bagi otak yang akan membebaskan cara pikir sinergisnya. 
Peneliti harus bisa menciptakan lingkungan yang kreatif agar siswa terbiasa untuk berpikir kreatif. Pertemuan pertama peneliti merancang praktikum tentang materi azas Black tetapi terdapat alat yang tidak tersedia yaitu gelas kimia. Siswa mulai kebingungan karena tidak tersedianya gelas kimia sebagai wadah air panas, dengan memberikan pertanyaanpertanyaan yang mengarahkan keterampilan berpikir kreatif siswa maka siswa tersebut akan terbiasa berpikir secara kreatif. Pertanyaanpertanyaan tesebut dimaksudkan agar siswa tidak terjebak dengan permasalahan yang ada padahal banyak alat pengganti gelas kimia yang bisa digunakan dalam praktikum tersebut. Hal tesebut yang membuat yang membuat peningkatan antara tes awal dan tes akhir.

Soal Nomor 2 memiliki peningkatan $\mathrm{N}$-gain ke 3 tertinggi dari soal yang lain. Hal tesebut disebabkan permasalahan yang diberikan sudah sering dialami oleh para siswa, sehingga jawabannya dapat dikatakan kreatif, baik tes awal maupun tes akhir sehingga bobot skor untuk jawaban siswa tidak memiliki perbedaan yang signifikan antara tes awal dan tes akhir tetapi perbedaan alasan antara tes akhir dan tes awal sangatlah berbeda.

Faktor alasan yang membuat skor soal Nomor 2 memiliki peningkatan. Sebagai contoh jawaban siswa pada tes awal mengatakan bahwa ia akan menggunakan selimut dan menggosokan minyak kayu putih dibadannya, jawabannya benar dan kreatif tetapi alasannya kurang memenuhi kriteria berpikir kreatif. Pada tes akhir siswa tersebut juga menjawab akan menggunakan selimut jika ia merasa dingin tetapi alasan mereka memilih cara tersebut sudah jelas dan rinci.
Pada Gambar 3, dapat dilihat peningkatan skor pada soal Nomor 2. Menurut Filsame (2007) kebanyakan kita terlahir disertai dengan penghalang dalam keterampilan berpikir kreatif, dengan menghilangkan penghalang-penghalang tersebut maka kita akan bisa mengasah keterampilan berpikir kreatif yang kita miliki.

Materi soal Nomor 2 berkaitan dengan konveksi, siswa dibagi menjadi 4 kelompok. Permasalahannya adalah hanya terdapat satu alat konveksi (dapat dilihat di LKS pertemuan ketiga) sementara terdapat 4 kelompok dalam kelas tersebut sehingga mengaruskan siswa untuk mengganti alat yang tidak tesedia tersebut. Salah satu tim berinisiatif mengganti alat tersebut dengan kardus yang terdapat dibelakang tempat duduk siswa sehingga kelompok yang lain ikut menggunakan kardus serta merancang kardus tersebut agar mirip dengan alat konveksi yang tidak tersedia. Setelah melakukan praktikum dan mengerjakan LKS siswa paham proses terjadinya konveksi sehingga terjadi peningkatan skor tes awal dan tes akhir.

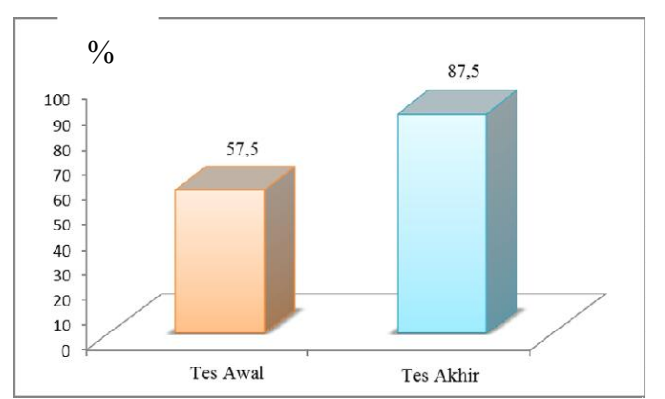

Gambar 3 Perbandingan skor rata-rata tes awal dan tes akhir soal nomor 2

Soal Nomor 3 memiliki peningkatan $\mathrm{N}$-gain ke dua. Hal tesebut dikarenakan perubahan pola pikir siswa. Kebanyakan siswa menjawab untuk mengambil spatula yang dipinjam tetangga, jawaban tersebut benar namun tidak 
kreatif. Setelah diberikan perlakukan problembased learning menggunakan praktikum alat sederhana terbukti terjadi perubahan berpikir kreatif tesebut. Siswa yang awalnya menjawab agar mengambil spatula yang dipinjam tetangga rata-rata menjawab agar menggunakan bahan yang terbuat dari isolator seperti kain lalu melilitnya pada sendok yang akan kita gunakan memasak.

Segi alasan sudah terlihat peningkatan berpikir kreatif yang sangat signifikan. Dari segi alasan pastu juga memiliki perubahan yang signifikan, misalnya siswa yang mimilih mengambil spatula yang dipinjam tetangga dengan alasan lebih cepat, pada tes akhir siswa memberikan alasan yang sangat memuaskan, hal tesebut karena siswa sudah paham prinsip konduksi yang diajarkan dan cara memecahkan masalah melalui metide praktikum alat sederhana, LKS yang diberikan menuntut siswa merancang suatu alat yang terdapat proses konveksi.

Sesuai dengan Filsaime [3] yang menyatakan jika seorang guru dapat menghilangkan penghalang-penghalang dari daya berpikir kreatif siswa maka siswa tersebut akan mengalami peningkatan berpikir kreatif secara fleksibel. Hal tesebut dapat dilihat pada Gambar 4, dimana terjadi peningkatan skor pada tes akhir setelah diterapkannya model problem-based learning menggunakan praktikum alat sederhana.

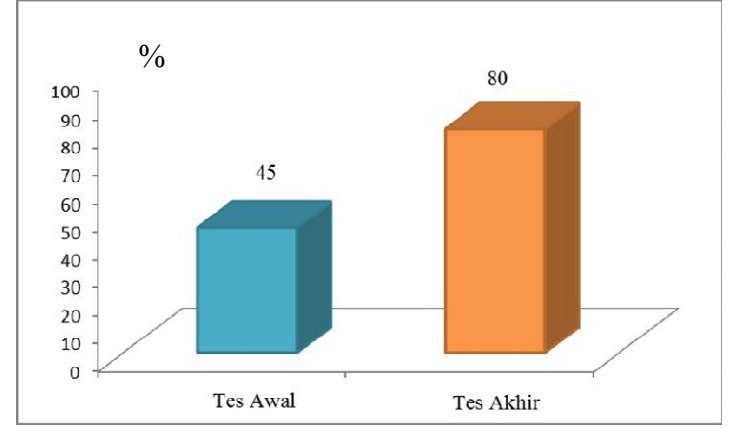

Gambar 4 Perbandingan nilai rata-rata tes awal dan tes akhir soal Nomor 3

Terakhir adalah soal yang memiliki peningkatan $\mathrm{N}$-gain terbesar yaitu nomor 4 . Sama halnya dengan jawaban mereka pada nomor 3 yaitu benar namun tidak kreatif. Pada tes awal kebanyakan siswa menyarankan ayah mereka mencari pekerjaan lain selain nelayan sedangkan pada tes akhir mereka menjawab dengan menyarankan ayah menggunakan layar dan memanfaatkan angin darat dan angin laut. Perbedaan pola berpikir kreatif tersebut disebabkan pada RPP pertemuan terakhir terdapat LKS yang praktikumnya tentang konveksi menggunakan alat sederhana, kebanyakan siswa telah paham tentang adanya persitiwa konveksi dalam kehidupan sehari-hari setelah pertemuan terakhir tersebut. Karena terdapat praktikum menggunakan alat sederhana dan terdapat LKS yang berisi pertanyaan mengenai perpindahan kalor.

Faktor perubahan pola pikir yang membuat siswa lancar dalam menjawab soal Nomor 4 dan memiliki $\mathrm{N}$-gain tertinggi dari soal yang lain dan indikator yang lain. Hal tesebut dapat dilihat dalam Gambar 5. 


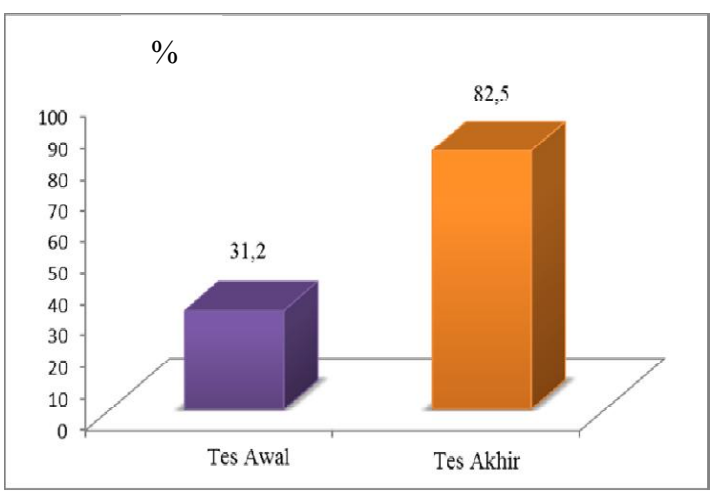

Gambar 5 Perbandingan nilai rata-rata tes awal dan tes akhir soal Nomor 4

Pada indikator fleksibilitas yang terdapat pada soal nomor 1, 2, 3 dan 4 memiliki peningkatan yang signifikan. Hal tersebut karena model problem-based learning menggunakan praktikum alat sederhana yang diterapkan di kelas $X_{B}$ lebih cenderung mengarahkan siswa untuk terampil berpikir secara fleksibel dan elaborasi. Saat membagikan LKS awalnya siswa kebingungan banyak alat praktikum yang kurang lengkap, disinilah proses berpikir secara fleksibel siswa dilatih dengan memberikan pertanyaanpertanyaan yang membantu siswa dalam memecahkan masalah dengan cara fleksibel.

Elaborasi yang merupakan indikator soal nomor 1 juga memiliki peningkatan skor yang signifikan. Hal tersebut karena guru membiasakan siswa untuk aktif dan membiasakan siswa untuk memberikan alasan dalam memberikan jawaban yang diberikan oleh guru, sehingga ketarampilan berpikir kreatif siswa menjadi terasah.

Setelah dilakukan uji hipotesis dengan menggunakan uji Wilcoxon diperoleh $\mathrm{W}_{\text {hitung }}=$ 0 dan $W_{\text {tabel }}=60$ pada taraf nyata $a=0,05$. Nilai yang diperoleh tabel > thitung, dengan demikian $\mathrm{H}_{0}$ ditolak dengan taraf nyata $\alpha=$ 0,05 dan $H_{1}$ diterima. Berdasarkan hasil tersebut diketahui bahwa terdapat perbedaan secara signifikan keterampilan berpikir kreatif siswa pada skor tes akhir dibandingkan dengan skor tes awal.

Model problem-based learning menggunakan praktikum alat sederhana yang diterapkan di kelas $X_{B}$ lebih cenderung mengarahkan siswa untuk terampil berpikir secara fleksibel dan elaborasi. Saat membagikan LKS awalnya siswa kebingungan banyak alat praktikum yang kurang lengkap, disinilah proses berpikir secara fleksibel siswa dilatih dengan memberikan pertanyaanpertanyaan yang membantu siswa dalam memecahkan masalah dengan cara fleksibel. Dalam menjawab pertanyaan yang diberikan peneliti selalu membiasakan siswa untuk menjelaskan permasalahan secara rinci, sehingga ketarampilan berpikir kreatif siswa menjadi terasah.

\section{KESIMPULAN}

Berdasarkan hasil penelitian dan analisis data hasil penelitian maka dapat disimpulkan bahwa penerapan problem-based learning menggunakan praktikum alat sederhana dapat meningkatkan keterampilan berpikir kreatif. Pada kelas yang diteliti setiap aspek keterampilan berpikir kreatif mengalami peningkatan dan berada dalam katagori sedang baik aspek elaborasi dan fleksibilitas.

\section{DAFTAR PUSTAKA}

[1] Mustafit (2008). Implementasi Problem Solving Laboratory Sebagai Model Kegiatan Laboratorium Berbasis Inquiry Untuk Meningkatkan Pemahaman Konsep Kesetimbangan Benda Pada Mahasiswa Fisika Semester II Tahun Ajaran 2007/2008. Universitas Negeri Semarang. 
[2] Awang. (2008). Creative Thinking Skill Approach Through Problem-Based Learning. World Academy of Science, Engineering and Technology. 2 (4) 31-36

[3] Filsaime (2007). Menguak Rahasia Berpikir Kritis dan Kreatif. Jakarta : Pustakarya 